\title{
PENERAPAN MODEL PEMBELAJARAN PRAKTIK BERBASIS COLLABORATIVE SKILL SEBAGAI UPAYA PENINGKATAN MUTU PENDIDIKAN TINGGI VOKASI
}

\author{
Dwi Rahdiyanta ${ }^{1}$, Putut Hargiyarto ${ }^{2}$, Asnawi $^{3}$ \\ 1,2,3 Jurusan Pendidikan Teknik Mesin FT-UNY \\ dwi_rahdiyanta@uny.ac.id
}

\begin{abstract}
This study aims to: (1) discover a collaborative skills-based learning model for practical work in vocational education programs which can improve the quality of learning outcomes; (2) determine the effect of the application of collaborative skills-based learning model for practical work towards the students' attitude and learning outcome. This $R \& D$ and experiments research was carried out in manufacturing industry of machining field in Yogyakarta, and in the Mechanical Engineering Department of Faculty of Engineering, Yogyakarta State University. The population being studied was all of Diploma students of Mechanical Engineering study program who enrolled in Complex Machining Processes course. Research sample of 33 students, divided in two groups, were determined by purposive sampling technique. The experiment was carried out by posttest-only control design. Content validation was done by expert judgment and items reliability with Alpha Cronbach formula and KR-20. Data were analyzed using descriptive analysis and t-test, with significance level of 0.05. The results show that: (1) The collaborative skills-based learning model for practical work is suitable to be implemented in order to improve the quality of learning outcomes in practical work; (2) The students' attitude and learning achievement of the model class is better, or higher, than the controlled class.
\end{abstract}

Keywords: Practical work, learning model, collaborative skills, vocational education

\begin{abstract}
ABSTRAK
Penelitian ini bertujuan untuk: (1) menemukan model pembelajaran praktik berbasis collaborative skill pada program pendidikan vokasi yang dapat meningkatkan kualitas hasil belajar; (2) mengetahui pengaruh penerapan model pembelajaran praktik berbasis collaborative skill terhadap sikap dan prestasi belajar mahasiswa. Penelitian R\&D dan eksperimen ini dilaksanakan di industri manufaktur bidang pemesinan di wilayah DIY dan di Jurusan Pendidikan Teknik Mesin FT-UNY. Populasi penelitian adalah seluruh mahasiswa program studi D3 Teknik Mesin FT-UNY yang melaksanakan kuliah Proses Pemesinan Kompleks. Pemilihan sampel ditentukan dengan teknik purposive sampling. Eksperimen dilaksanakan dengan rancangan posttest-only control design. Validasi isi dilakukan dengan expert judgement dan reliabilitas butir dengan formula Alpha Cronbach dan KR-20. Data dianalisis dengan analisis deskriptif dan uji-t, taraf signifikansi 0,05. Hasil penelitian menunjukkan bahwa: (1) model pembelajaran praktik berbasis collaborative skill cocok digunakan untuk meningkatkan kualitas hasil belajar praktik; (2) Sikap dan prestasi belajar praktik mahasiswa pada kelas model lebih baik atau lebih tinggi dibanding kelas kontrol.
\end{abstract}

Kata kunci: Model pembelajaran praktik, collaborative skill, pendidikan vokasi

\section{PENDAHULUAN}

Pendidikan tinggi vokasi sebagai bagian dari sistem pendidikan nasional memainkan peran yang sangat strategis bagi terwujudnya tenaga kerja yang terampil dan siap kerja. Berbagai kajian menunjukkan bahwa peluang pertumbuhan ekonomi yang tinggi dan berkelanjutan dari suatu negara akan semakin besar jika didukung oleh SDM yang memiliki: (1) pengetahuan dan kemampuan dasar untuk menyesuaikan diri dengan tuntutan dan dinamika perkembangan yang tengah berlangsung; (2) jenjang pendidikan yang semakin tinggi; (3) keterampilan keahlian yang berlatar belakang ilmu pengetahuan dan teknologi (iptek); dan (4) kemampuan untuk menghasilkan produk-produk baik dari kualitas maupun harga, mampu bersaing dengan produk-produk lainnya di pasar global. 
Berdasarkan kenyataan tersebut, menjadi tanggung jawab dunia pendidikan khususnya pendidikan vokasi untuk dapat menghasilkan lulusan yang kompeten. Oleh karena itu kompetensi yang akan dikembangkan melalui proses pembelajaran harus merujuk pada kompetensi yang dibutuhkan oleh dunia industri. Salah satu mata kuliah di perguruan tinggi vokasi yang sangat penting dan strategis untuk pembentukan kompetensi adalah mata kuliah praktik. Oleh sebab itu dipandang sangat penting untuk selalu meningkatkan mutu proses pembelajaran praktik. Berdasarkan prasurvei yang telah dilaksanakan di industri manufaktur, diperoleh informasi bahwa proses pembuatan satu unit produk memerlukan kolaborasi (kerja sama) dari berbagai keterampilan (collaborative skill). Hasil akhir dari produk yang diharapkan tidak dapat tercapai tanpa ada kerja sama yang baik. Salah satu upaya untuk menanamkan sikap dan perilaku peserta didik terkait dengan kompetensi yang dituntut oleh dunia industri tersebut adalah dengan mengembangkan model pembelajaran praktik melalui pendekatan collaborative skill.

Calhoun and Finch, (1976: 2) menjelaskan bahwa pendidikan vokasi adalah suatu program pendidikan yang secara langsung dihubungkan dengan persiapan seseorang untuk memasuki dunia kerja, atau untuk persiapan tambahan yang diperlukan dalam suatu karir. Finch dan Crunkilton (1979: 2) juga menjelaskan bahwa pendidikan vokasi diartikan sebagai pendidikan yang memberikan bekal kepada peserta didik agar dapat bekerja guna menopang kehidupannya. Pendidikan vokasi sebagaimana pendapat di atas diperlukan untuk menyiapkan peserta didik agar siap kerja baik di dalam lingkungan maupun di luar lingkungan masyarakat. Selaras dengan hasl tersebut maka misi utama para pendidik dan pembuat kebijakan adalah menyiapkan pondasi yang kuat dalam proses belajar mengajar bagi para peserta didik untuk penguasaan dan penerapan keterampilan akademis maupun konsep-konsep yang diperlukan untuk menghadapi dunia kerja yang sesungguhnya.
Wardiman (1998) menjelaskan bahwa karakteristik pendidikan vokasi memiliki ciri: (1) diarahkan untuk mempersiapkan peserta didik memasuki lapangan kerja, (2) didasarkan atas "demand-driven" (kebutuhan dunia kerja), (3) ditekankan pada penguasaan pengetahuan, keterampilan, sikap dan nilai-nilai yang dibutuhkan oleh dunia kerja, (4) penilaian terhadap kesuksesan peserta didik harus pada "hands-on" atau performa dunia kerja, (5) hubungan yang erat dengan dunia kerja merupakan kunci sukses pendidikan vokasi, (6) bersifat responsive dan antisipatif terhadap kemajuan teknologi, (7) lebih ditekankan pada "learning by doing" dan hands-on experience, (8) memerlukan fasilitas yang mutakhir untuk praktik, (9) memerlukan biaya investasi dan operasional yang lebih besar daripada pendidikan umum.

Titik berat pendidikan vokasi adalah membekali peserta didik dengan seperangkat keterampilan dan kemampuan (kompetensi) yang dapat digunakan untuk bekerja dalam bidang tertentu atau mengembangkan diri sesuai bidang keahliannya. Penyusunan standar kompetesi yang sesuai dengan bidang-bidang keahlian tertentu sangat dibutuhkan sebagai refleksi atas kompetensi yang diharapkan dimiliki oleh setiap lulusan pendidikan kejuruan, sehingga ke depan pendidikan vokasi memberikan andil besar terhadap kemajuan pembangunan di segala bidang kehidupan dan menempatkan SDM pada posisi terhormat sejajar dengan bangsa-bangsa lain.

Marzano (1993), menjelaskan bahwa pembelajaran kolaboratif adalah suatu filsafat personal, bukan sekadar teknik pembelajaran di kelas. Lebih lanjut dinyatakan bahwa kolaborasi adalah filsafat interaksi dan gaya hidup yang menjadikan kerjasama sebagai suatu struktur interaksi yang dirancang sedemikian rupa guna memudahkan usaha kolektif untuk mencapai tujuan bersama. Pembelajaran kolaboratif dapat didefinisikan sebagai filsafat pembelajaran yang memudahkan para peserta didik bekerjasama, saling membina, belajar dan berubah bersama, serta maju bersama pula. 
Struktur tujuan kolaboratif dicirikan oleh jumlah saling ketergantungan yang begitu besar antar peserta didik dalam kelompok. Dalam pembelajaran kolaboratif, peserta didik mengatakan "we as well as you", dan siwa akan mencapai tujuan hanya jika peserta didik lain dalam kelompok yang sama dapat mencapai tujuan mereka bersama (Arends, 1998; Heinich et al., 2002; Slavin, 1995; Qin \& Johnson, 1995).

Pembelajaran kolaboratif juga dapat menyediakan peluang untuk menuju pada kesuksesan praktik-praktik pembelajaran. Sebagai teknologi untuk pembelajaran (technology for instruction), pembelajaran kolaboratif melibatkan partisipasi aktif para peserta didik dan meminimisasi perbedaanperbedaan antar individu. Pembelajaran kolaboratif telah menambah momentum pendidikan formal dan informal dari dua kekuatan yang bertemu, yaitu: (1) realisasi praktik, bahwa hidup di luar kelas memerlukan aktivitas kolaboratif dalam kehidupan di dunia nyata; (2) menumbuhkan kesadaran berinteraksi sosial dalam upaya mewujudkan pembelajaran bermakna.

Johnson (1995) menjelaskan bahwa sekurang-kurangnya terdapat lima unsur dasar agar dalam suatu kelompok terjadi pembelajaran kolaboratif, yaitu: (a) Saling ketergantungan positif. Setiap peserta didik harus merasa bahwa ia bergantung secara positif dan terikat dengan antar sesama anggota kelompoknya dengan tanggung jawab menguasai bahan pelajaran dan memastikan bahwa semua anggota kelompoknya pun menguasainya. Mereka merasa tidak akan sukses bila peserta didik lain juga tidak sukses. (b) Interaksi langsung antar peserta didik. Hasil belajar yang terbaik dapat diperoleh dengan adanya komunikasi verbal antarpeserta didik yang didukung oleh saling ketergantungan positif. Peserta didik harus saling berhadapan dan saling membantu dalam pencapaian tujuan belajar. (c) Pertanggungajawaban individu. Setiap peserta didik dituntut harus menguasai materi yang dijadikan pokok bahasan agar dalam suatu kelompok peserta didik dapat menyumbang, mendukung dan membantu satu sama lain. Setiap anggota kelompok bertanggung jawab untuk mempelajari pokok bahasan dan bertanggung jawab pula terhadap hasil belajar kelompok. (d) Keterampilan berkolaborasi. Keterampilan sosial peserta didik sangat penting dalam pembelajaran. Peserta didik dituntut mempunyai keterampilan berkolaborasi, sehingga dalam kelompok tercipta interaksi yang dinamis untuk saling belajar dan membelajarkan sebagai bagian dari proses belajar kolaboratif. (e) Keefektifan proses kelompok. Peserta didik memproses keefektifan kelompok belajarnya dengan cara menjelaskan tindakan mana yang dapat menyumbang belajar dan mana yang tidak serta membuat keputusan-keputusan tindakan yang dapat dilanjutkan atau yang perlu diubah.

Collaborative skill dapat diartikan sebagai perpaduan atau gabungan berbagai kemampuan atau keterampilan. Hal ini dapat dijelaskan bahwa produk collaborative skill merupakan produk yang dihasilkan dari beberapa jenis pekerjaan dengan keterampilan yang berbeda. Implikasi dalam pembelajaran praktik adalah diwujudkan dalam materi pembelajaran atau bahan ajarnya. Pelaksanaan pembelajaran kolaboratif dalam praktik pemesinan adalah peserta didik diberikan jobsheet untuk mengerjakan sebuah benda kerja dengan menggunakan mesin perkakas. Penerapan pembelajaran praktik berbasis collaborative skill ini memerlukan materi pembelajaran yang berupa job-sheet yang harus dikembangkan terlebih dahulu untuk memenuhi kriteria collaborative skill. Jenis job/pekerjaan yang akan diberikan kepada mahasiswa merupakan job yang tersusun dari banyak komponen. Pelaksanaan proses pembelajaran dengan membagi peserta didik menjadi beberapa kelompok, dimana setiap anggota memiliki tugas mengerjakan satu komponen yang kemudian dapat dipasangkan dalam satu kelompoknya menjadi satu unit benda kerja. Hal tersebut akan membuat peserta didik lebih termotivasi dalam melaksanakan pembelajaran 
dan benar-benar maksimal dalam berusaha menguasai kompetensi, karena keberhasilan kelompok merupakan keberhasilan setiap individu sehingga mereka merasa tidak akan sukses bila peserta didik lain juga tidak sukses.

Permasalahan yang dibahas dalam penelitian ini adalah: (1) apakah model pembelajaran praktik berbasis collaborative skill dapat meningkatkan kualitas hasil belajar praktik, dan (2) apakah ada perbedaan sikap/ perilaku maupun prestasi belajar antara mahasiswa yang diajar dengan menggunakan model pembelajaran praktik berbasis collaborative skill dengan mahasiswa yang tidak diajar dengan model pembelajaran praktik berbasis collaborative skill.

\section{METODE}

Penelitian ini menggunakan pendekatan Research and Development (Borg \& Gall, 1998:536) dan dilanjutkan dengan eksperimen. Model pengembangan dalam penelitian ini melalui tahap model konseptual, model teoretik, model hipotetik, dan model final. Pengembangan model pada penelitian ini melalui kegiatan FGD (Focus Group Discussion), teknik Delphi, dan eksperimen, sebagaimana ditunjukkan pada Gambar 1.

\section{Tahapan Penelitian}

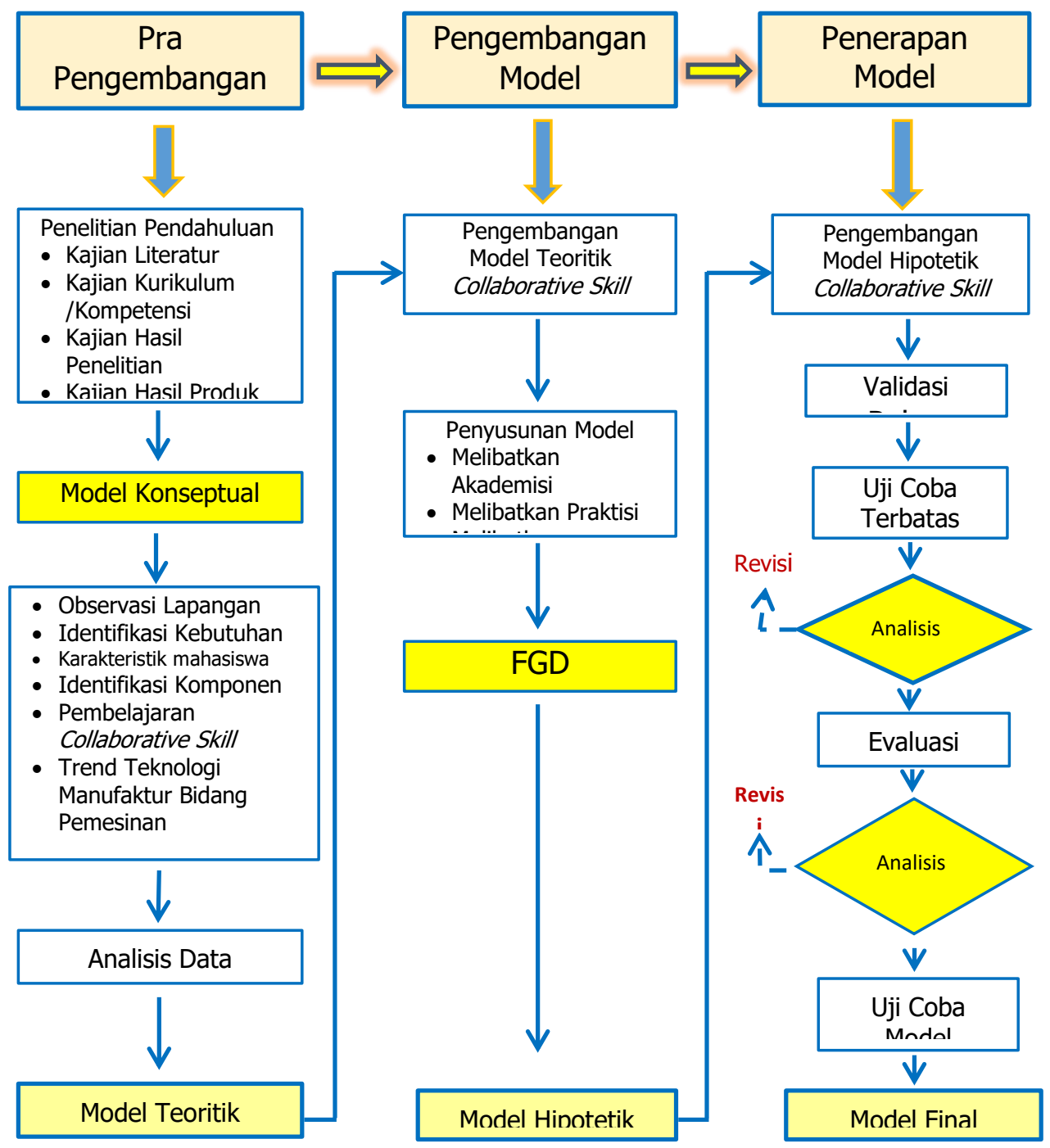

Gambar 1. Model pengembangan 
Kegiatan implementasi model pembelajaran praktik berbasis collaborative skill pada mata kuliah praktik pemesinan ini dilakukan dengan menggunakan desain eksperimen posttest-only control design. Hal ini disesuaikan dengan karakteristik pembelajaran praktik dimana untuk penilaian prestasi mahasiswa dilihat dari benda kerja hasil praktik, sehingga tidak diperlukan pretest. Adapun desain penelitian tersebut dapat dilihat pada Gambar 2 di bawah ini:

$$
\begin{array}{lll}
\mathrm{R} & \mathrm{X} & \mathrm{O} 2 \\
\mathrm{R} & & \mathrm{O} 4
\end{array}
$$

\section{Gambar 2. Posttest-Only Control Design}

\section{Keterangan :}

$\mathrm{R}=$ kelas kontrol dan kelas uji coba diambil secara random

$\mathrm{O} 2$ = posttest kelas uji coba

$\mathrm{O} 4$ = posttest kelas control
Lokasi untuk kegiatan penelitian ini adalah di Jurusan Pendidikan Teknik Mesin Fakultas Teknik Universitas Negeri Yogyakarta, dan industri manufakturing bidang pemesinan yang ada di Yogyakarta. Teknik pengumpulan data pada penelitian adalah: (1) lembar observasi, (2) dokumentasi, (3) wawancara untuk menggali tanggapan baik dari mahasiswa maupun dosen pengajar, dan (4) lembar penilaian benda kerja hasil praktik secara self assessment. Data hasil penelitian dianalisis dengan cara kualitatif dan kuantitatif. Untuk menguji keefektifan model yang dikembangkan dibandingkan dengan model yang lama, dianalisis dengan menggunakan $t$-test.

\section{HASIL DAN PEMBAHASAN}

Rumusan model final yang diimplementasikan pada penelitian ini dapat dilihat pada Gambar 3 berikut.

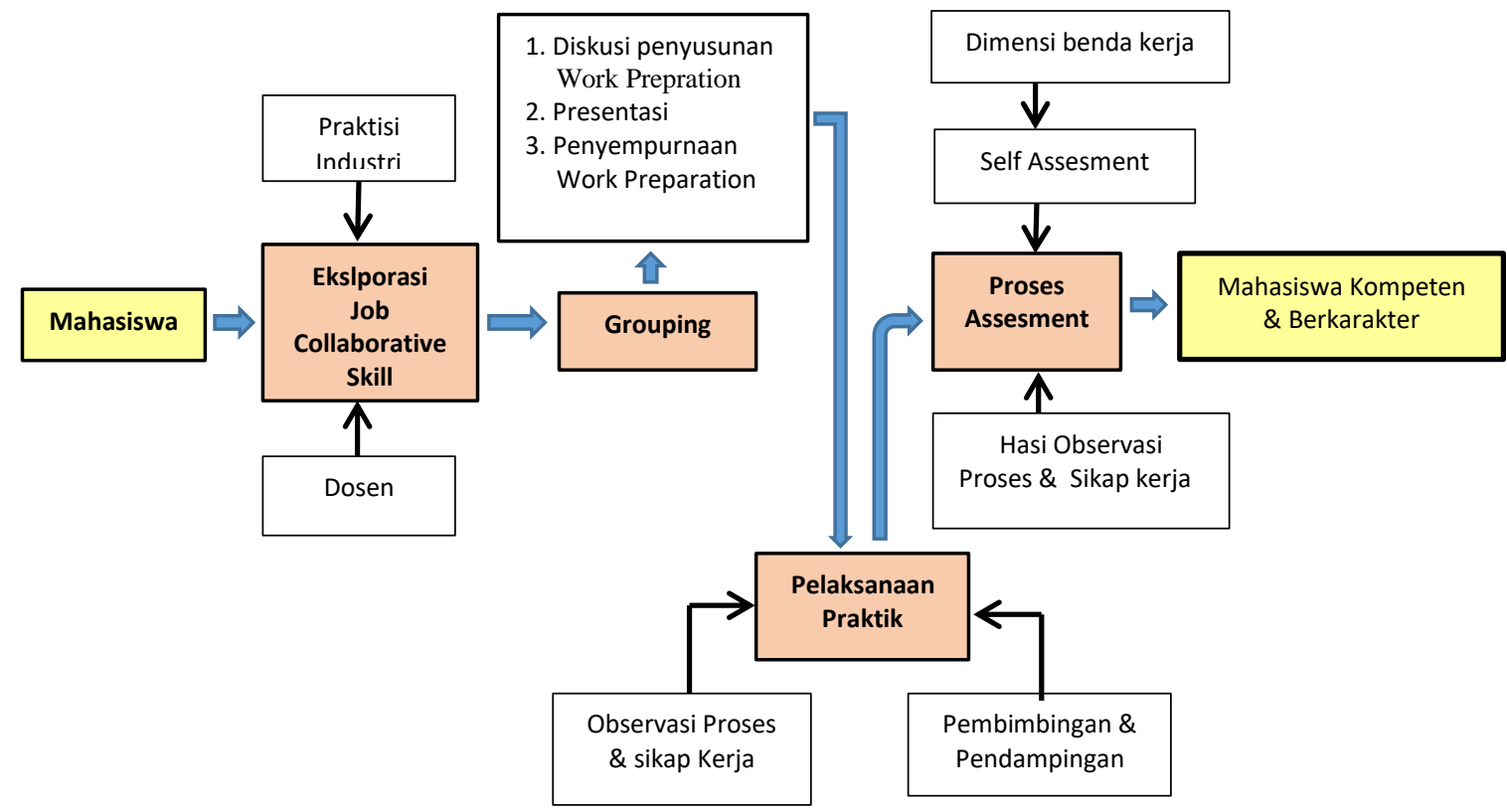

Gambar 3. Model Final

Penelitian ini dilaksanakan pada mata kuliah Proses Pemesinan kompleks yang diajarkan pada mahasiswa semester 4 Jurusan Pendidikan Teknik Mesin FT-UNY. Proses penelitian dilaksanakan selama delapan pertemuan. Pertemuan kesatu sampai dengan ketiga digunakan untuk penjelasan dan persiapan kegiatan pembelajaran, sedangkan pertemuan keempat sampai dengan kedelapan merupakan inti dari kegiatan penelitian, sehingga setiap pertemuan diamati perkembangan aktivitas mahasiswa terkait dengan penerapan aspek karakter maupun yang terkait dengan prestasi belajar atau kemampuan mahasiswa pada mata kuliah Proses Pemesinan Kompleks. Sesuai dengan karakteristik mata kuliah praktik, maka aspek karakter yang diterapkan adalah jujur, disiplin, tekun, teliti, mandiri, kerja keras dan 
peduli. Sedangkan aspek prestasi belajar mahasiswa tercermin dalam pengerjaan jobsheet pada mata kuliah Proses Pemesinan Kompleks yang telah ditetapkan.

Data hasil observasi terhadap tingkah laku atau aktivitas mahasiswa terkait dengan penerapan aspek sikap pada kelas eksperimen, dapat dilihat dalam Tabel 1, sedangkan data hasil observasi terhadap sikap atau aktivitas mahasiswa pada kelas kontrol, dapat dilihat pada Tabel 2 berikut ini.

Tabel 1. Aktivitas mahasiswa kelas eksperimen

\begin{tabular}{|c|c|c|c|c|c|c|c|c|}
\hline \multirow{2}{*}{ Aspek Sikap/perilaku } & \multicolumn{6}{|c|}{ Jumlah Mahasiswa pada pertemuan ke } & \multirow{2}{*}{ Rata-rata } & \multirow{2}{*}{ Prosentase } \\
\hline & $\mathrm{I}$ & II & III & IV & $\mathrm{V}$ & VI & & \\
\hline Jujur & 9 & 11 & 12 & 13 & 15 & 16 & 12.6 & 0.79 \\
\hline Disiplin & 12 & 14 & 14 & 15 & 16 & 16 & 14.5 & 0.90 \\
\hline Tekun & 6 & 10 & 11 & 13 & 15 & 16 & 12.0 & 0.75 \\
\hline Teliti & 7 & 9 & 10 & 12 & 14 & 15 & 11.8 & 0.74 \\
\hline Mandiri & 6 & 9 & 12 & 14 & 14 & 15 & 11.7 & 0.73 \\
\hline Kerja keras & 6 & 10 & 12 & 15 & 14 & 14 & 11.8 & 0.74 \\
\hline \multirow[t]{2}{*}{ Peduli } & 9 & 10 & 14 & 14 & 15 & 16 & 13.0 & 0.81 \\
\hline & \multicolumn{6}{|c|}{ Rata-rata } & 12.27 & $\mathbf{0 . 7 8}$ \\
\hline
\end{tabular}

Tabel 2. Aktivitas mahasiswa kelas kontrol

\begin{tabular}{lccccccccc}
\hline \multirow{2}{*}{ Aspek Sikap } & \multicolumn{4}{c}{ Jumlah Mahasiswa pada pertemuan ke } & \multirow{2}{*}{ Rata-rata } & \multirow{2}{*}{ Prosentase } \\
\cline { 1 - 6 } Jujur & I & II & III & IV & V & VI & Ratann \\
Disiplin & 7 & 7 & 8 & 8 & 11 & 12 & 8.8 & 0.55 \\
Tekun & 6 & 9 & 9 & 11 & 10 & 11 & 9.3 & 0.58 \\
Teliti & 5 & 6 & 6 & 7 & 7 & 10 & 6.5 & 0.38 \\
Mandiri & 5 & 6 & 5 & 5 & 6 & 8 & 5.8 & 0.36 \\
Kerja keras & 5 & 5 & 6 & 7 & 8 & 9 & 6.6 & 0.54 \\
Peduli & 6 & 5 & 6 & 7 & 5 & 7 & 6.0 & 0.38 \\
& 6 & 6 & 7 & 8 & 10 & 11 & 8.0 & 0.50 \\
& Rata-rata Keseluruhan & & & & $\mathbf{6 . 4 6}$ & $\mathbf{0 . 4 7}$ \\
\hline
\end{tabular}

$\underline{\text { Tabel 3. Prestasi belajar mahasiswa }}$

\begin{tabular}{|c|c|c|c|c|c|c|c|c|}
\hline \multirow{3}{*}{$\begin{array}{l}\text { M } \\
\text { hs }\end{array}$} & \multicolumn{6}{|c|}{ Job Praktik } & \multirow{2}{*}{\multicolumn{2}{|c|}{ Rata-rata }} \\
\hline & \multicolumn{2}{|c|}{ I } & \multicolumn{2}{|c|}{ II } & \multicolumn{2}{|c|}{ III } & & \\
\hline & $\mathrm{T} 1$ & $\mathrm{~T} 2$ & $\mathrm{~T} 1$ & $\mathrm{~T} 2$ & $\mathrm{~T} 1$ & $\mathrm{~T} 2$ & $\mathrm{~T} 1$ & $\mathrm{~T} 2$ \\
\hline 1 & 80 & 65 & 85 & 66 & 86 & 70 & 83.67 & 67.00 \\
\hline 2 & 78 & 60 & 85 & 65 & 87 & 65 & 83.33 & 63.33 \\
\hline 3 & 80 & 70 & 78 & 68 & 80 & 68 & 79.33 & 68.67 \\
\hline 4 & 75 & 72 & 85 & 70 & 87 & 70 & 82.33 & 70.67 \\
\hline 5 & 78 & 68 & 80 & 70 & 85 & 66 & 81.00 & 68.00 \\
\hline 6 & 80 & 72 & 80 & 60 & 85 & 60 & 81.67 & 64.00 \\
\hline 7 & 82 & 68 & 87 & 62 & 82 & 65 & 83.67 & 65.00 \\
\hline 8 & 80 & 70 & 80 & 65 & 84 & 62 & 81.33 & 65.67 \\
\hline 9 & 78 & 70 & 80 & 60 & 78 & 66 & 78.67 & 65.33 \\
\hline 10 & 80 & 65 & 80 & 65 & 82 & 72 & 80.67 & 67.33 \\
\hline 11 & 85 & 60 & 76 & 72 & 80 & 68 & 80.33 & 66.67 \\
\hline 12 & 75 & 70 & 86 & 66 & 80 & 60 & 80.33 & 65.33 \\
\hline 13 & 80 & 65 & 80 & 70 & 82 & 65 & 80.67 & 66.67 \\
\hline 14 & 80 & 60 & 82 & 65 & 85 & 65 & 82.33 & 63.33 \\
\hline 15 & 75 & 70 & 85 & 66 & 80 & 60 & 80.00 & 65.33 \\
\hline 16 & 82 & 72 & 80 & 60 & 85 & 60 & 82.33 & 64.00 \\
\hline 17 & 81 & 72 & 80 & 70 & 82 & 70 & 81.00 & 70.67 \\
\hline \multicolumn{7}{|c|}{ Rata-rata } & 81.35 & 66.29 \\
\hline
\end{tabular}

\section{Keterangan:}

$\mathrm{T} 1=$ Kelas eksperimen, $\mathrm{T} 2=$ Kelas kontrol
Job I: Roda gigi cacing; Job II: Poros roda gigi cacing; Job III: Ulir cacing

Data tentang prestasi belajar mahasiswa diambil dari penilaian benda kerja hasil praktik sebanyak tiga (3) job praktik. Secara lengkap, data tersebut dapat dilihat pada Tabel 3.

Tahap selanjutnya dilakukan uji persyaratan analisis sesuai dengan jenis analisis yang akan digunakan yaitu uji beda (t-test). Uji persyaratan analisis adalah uji normalitas dan homogenitas. Uji normalitas menggunakan metode nilai rasio skewness dan rasio kurtosis. Suatu data dapat dikatakan berdistribusi normal jika nilai rasio skewness dan nilai rasio kurtosis berada pada rentang -2 sampai dengan +2 (Muhammad Nisfiannoor, 2009). Hasil uji normalitas menunjukkan bahwa distribusi data baik untuk kelas kontrol maupun eksperimen berdistribusi normal, yaitu sebagai berikut: data 
kelas eksperimen, nilai rasio skewness variabel ($1,748)$ dan rasio kurtosis $(0,288)$, dan untuk kelas kontrol menunjukkan nilai rasio skewness variabel $(0,821)$ dan rasio kurtosis $(-0,370)$.

Uji Homogenitas data hasil penelitian dilakukan dengan menggunakan levene statistic dan diperoleh signifikansi 0,189 pada Based on Mean yang lebih besar 0,05. Hasil pengujian data aktivitas belajar mahasiswa dengan levene statistic diperoleh signifikansi 0,189 pada Based on Mean yang lebih besar 0,05. Dengan demikian data penelitian tersebut adalah homogen. Berdasarkan hasil uji persyaratan analisis tersebut, maka uji beda dapat dilakukan dengan uji parametris, sehingga teknik uji yang digunakan adalah uji-t.

Berdasarkan hasil penelitian didapatkan nilai rata-rata prestasi belajar praktik kelas eksperimen adalah 81,35 sedangkan nilai ratarata prestasi belajar praktik kelas kontrol adalah 66,29. Berdasarkan hasil uji beda, diketahui nilai t-hitung $=10,573$ dengan $p=0,000$. Dengan demikian terbukti bahwa terdapat perbedaaan yang signifikan antara prestasi belajar mahasiswa kelas eksperimen dengan kelas control. Prestasi belajar kelas eksperimen lebih baik dari pada prestasi belajar kelas kontrol ( $\mathrm{X}_{\text {eksperimen }}=81,35>$ $\left.\mathrm{X}_{\text {kontrol}}=66,29\right)$.

Hasil penelitian mengenai aktivitas belajar mahasiswa, didapatkan bahwa $78 \%$ dari mahasiswa kelas eksperimen aktif, sedangkan untuk kelas kontrol hanya $47 \%$ dari mahasiswa yang aktif. Berdasarkan hasil uji beda, diketahui nilai t-hitung $=7,211$ dengan $\mathrm{p}=0,000$. Dengan demikian terbukti bahwa terdapat perbedaaan aktivitas belajar antara mahasiswa kelas eksperimen dengan kelas kontrol. Hal ini menunjukkan bahwa aktivitas belajar mahasiswa kelas eksperimen lebih baik dibandingkan dengan aktivitas belajar mahasiswa pada kelas control.

Berdasarkan hasil implementasi model pembelajaran collaborative skill yang telah dilaksanakan, secara kuantitatif terbukti bahwa dengan menerapkan model pembelajaran ini, mampu mengintegrasikan aspek sikap atau perilaku (karakter) sehingga terbentuk karakter peserta didik yang tercermin dari aktivitas peserta didik selama proses pembelajaran praktik. Hal ini dapat dilihat berdasarkan hasil pengamatan selama proses implementasi model.

Tahapan eksplorasi sikap kerja menunjukkan bahwa model pembelajaran praktik berbasis collaborative skill sangat efektif dalam menggali kesadaran peserta didik yang terkait dengan aspek sikap kerja. Tahapan ini mengharuskan semua peserta didik untuk menyampaikan pendapatnya terkait dengan aspek sikap kerja yang mestinya dimiliki oleh seseorang khususnya dalam melaksanakan proses pembelajaran praktik. Pelaksanaan tahapan ini memiliki tujuan apabila seseorang telah memiliki kesadaran secara teoritis terkait dengan aspek karakter (yang dilihat dari proses diskusi penyampaian pendapat oleh peserta didik terkait dengan aspek karakter), maka secara logis seseorang tersebut tentunya akan lebih mudah dan lebih terarah dalam melaksanakan aspek karakter dalam proses pembelajaran praktik. Hal tersebut terbukti dari hasil observasi terhadap aktivitas semua peserta didik selama proses pembelajaran berlangsung, peserta didik dengan tekun melaksanakan aspek-aspek sikap terkait dengan karakter kerja dengan baik. Sehingga model pembelajaran collaborative skill ini memang efektif dalam mengintegrasikan aspek karakter dalam proses pembelajaran praktik.

Tahapan penyusunan Work Preparation Sheet, juga menunjukkan aktivitas peserta didik yang sangat positif. Tahapan ini mengharuskan peserta didik untuk dapat bekerjasama dan menghargai dengan teman dalam kelompoknya maupun kelompok lain. Tahapan ini mampu membiasakan peserta didik untuk memiliki aspek karakter berani berpendapat, menghargai pendapat orang lain, dan kerjasama. Tahapan lain dalam rangka proses integrasi aspek karakter adalah pada saat proses penilaian benda kerja hasil praktik. Benda kerja hasil praktik terlebih dahulu dilakukan self assessment oleh peserta didik kemudian berikutnya dinilai oleh pengajar.

Peserta didik wajib melakukan pengukuran secara mandiri terhadap benda kerja mereka masing-masing kemudian hasil penilaiannya diisikan dalam lembar yang sudah disediakan. 
Data hasil penilaian secara mandiri oleh peserta didik tersebut kemudian dilakukan cross-check oleh pengajar. Kegiatan ini dapat menunjukkan tingkat kejujuran peserta didik terutama dalam melaksanakan self assessment.

Hasil implementasi menunjukkan bahwa secara global ada perbedaan pada aspek karakter peserta didik antara kelas eksperimen dengan kelas kontrol. Hal ini ditunjukkan dari perbedaan aktivitas peserta didik pada saat proses pembelajaran berlangsung. Kelas eksperimen jauh lebih aktif atau lebih baik bila dibandingkan dengan kelas kontrol. Hasil penelitian terkait dengan prestasi belajar peserta didik, menujukkan hasil pengamatan pada aktivitas belajar berbanding lurus dengan prestasi belajar peserta didik. Data yang diperoleh pada kelas eksperimen dimana tingkat aktivitasnya lebih baik maka capaian prestasi belajarnya juga jauh lebih tinggi dibandingkan dengan kelas kontrol. Beberapa fakta di atas, sesuai dengan penelitian yang dilakukan oleh Marvin Berkowitz (2000), menunjukan adanya peningkatan motivasi peserta didik dalam meraih prestasi akademik pada sekolah-sekolah yang menerapkan pendidikan karakter.

Model pembelajaran praktik berbasis collaborative skill, merupakan pengembangan dari model pembelajaran CBT dimana dalam proses pembelajaran sekaligus mengintegrasikan aspek-aspek sikap atau perilaku. Model ini lebih dikhususkan untuk pembelajaran praktik, dimana dalam pembelajaran ini menonjolkan aspek kompetensi praktik atau keterampilan peserta didik. Aspek sikap atau tingkah laku yang diintegrasikan tentunya dapat disesuaikan dengan karakter kerja mata kuliah yang akan diterapkan.

\section{SIMPULAN}

Hasil penelitian dan pembahasan di atas dapat disimpulkan sebagai berikut ini: (a) Model pembelajaran praktik berbasis collaborative skill cocok digunakan untuk meningkatkan kualitas proses pembelajaran praktik pemesinan. (b) Terdapat perbedaan sikap (aktivitas/perilaku) belajar antara mahasiswa yang diajar dengan menerapkan model pembelajaran praktik berbasis collaborative skill, dibandingkan dengan kelas yang tidak menerapkan model pembelajaran praktik berbasis collaborative skill $(\mathrm{t}=7,211 ; \mathrm{p}=$ 0,000). Aktivitas mahasiswa setelah diterapkan model pembelajaran praktik berbasis collaborative skill mengalami peningkatan yang lebih baik dibandingkan dengan kelas control $(0.78>0.47)$. (c) Terdapat perbedaan prestasi belajar praktik mahasiswa antara mahasiswa yang diajar dengan menerapkan model pembelajaran praktik berbasis collaborative skill, dibandingkan dengan kelas yang tidak menerapkan model pembelajaran praktik berbasis collaborative skill $(\mathrm{t}=10,573 ; \mathrm{p}=$ praktik mahasiswa yang diajar dengan menerapkan model pembelajaran praktik berbasis collaborative skill lebih tinggi dibandingkan dengan prestasi belajar mahasiswa yang diajar tidak menggunakan model pembelajaran praktik berbasis collaborative skill $\left(\mathrm{X}_{\text {eksperimen }}=81,35>\right.$ $\left.X_{\text {kontrol }}=66,29\right)$.

Beberapa hal berikut ini dapat dijadikan pertimbangan dalam pelaksanaan pembelajaran kolaboratif, yaitu: (a) Model pembelajaran collaborative skill yang telah dikembangkan ini telah terbukti dapat meningkatkan sikap kerja dan prestasi belajar peserta didik. Oleh sebab itu model pembelajaran ini perlu diuji cobakan untuk matakuliah praktik yang lain. (b) Penerapan model pembelajaran praktik berbasis collaborative skill ini lebih banyak porsi penekanan pada aktivitas peserta didik pada saat proses pembelajaran berlangsung, sehingga peran dosen/pengajar hendaknya lebih fokus dalam proses pembimbingan dan pendampingan kepada peserta didik.

\section{DAFTAR RUJUKAN}

Arends, R. I. (1998). Learning to teach. Singapore: McGraw-Hill book Company.

Berkowitz, M. W. (2000). The Education of Complete Moral Person. Dalam buletin, Character Educator, yang diterbitkan oleh Character Education Partnership.Borg, W.R., \& Gall, M. D. (1998). Educational Research, an introduction. New York: Longman. 
Borg, W.R., \& Gall, M. D. (1998). Educational Research, an introduction. New York: Longman.

Calhoun, C.C. and Finch, C.R. (1976).Vocational educational: Concepts and operation, Belmont: Wadsworth Publishing Company.

Finch, C.R. and Crunkilton, J.R. (1979). Curriculum development in vocational education, Boston: Allyn and Bacon Inc.

Heinich, R., Molenda, M., Russell, J. D., \& Smaldino, S. E. (2002). Instructional media and technology for learning, 7th edition. New Jersey: Prentice Hall, Inc.
Johnson, D. W., \& Johnson, R. T., Qin, Z. (1995). Cooperative versus competitive efforts and problem solving. Review of Educational Research. 65(2). 129-143.

Marzano, R. J. (1993). How classroom teachers approach the teaching of thinking. Dalam Donmoyer, R., \& Merryfield, M. M (Eds.): Theory into practice: Teaching for higher order thinking. 32(3). 154-160.

Slavin, R. E. (1995). Cooperative learning. Second edition. Boston: Allyn and Bacon.

Wardiman Joyonegoro, (1998). Pengembangan sumberdaya manusia melalui SMK. Jakarta: PT. Jayakarta Agung Offset. 